\title{
THE ECONOMIC VALUE OF WATER FOR COMMERCIAL USE IN UPPER BRANTAS SUB-WATERSHED
}

\author{
Fitri Nurfatriani ${ }^{1,2}$ and Zahrul Muttaqin ${ }^{1}$
}

\begin{abstract}
This research was aimed at calculating the economic value of hydrological benefits associated with protecting forest in the upper Brantas Sub-watershed. The hydrological benefit was limited to commercial uses of water from the forest which included:. tap/ drinking water, hydropower generation, and industrial uses. The economic value was calculated using the full cost method in which the cost should be paid by all users gaining benefits. The calculated cost was futher used to determine a tariff for water usages, one that better reflected the sustainable use value of water.
\end{abstract}

Keywords: Economic valuation, hydrological benefits, protecting forest, full cost method

\section{INTRODUCTION}

The contribution of forestry sector to the economic development is often considered and calculated only from its tangible benefits as its intangible benefits are usually difficult to calculate. However, development of resource economics has provided several methods and techniques in quantifying intangible benefits of forest towards more comprehensive valuation of forest resources related to the choices of forestland uses (Bishop, 1999).

Economic valuation of natural resource benefits can illustrate mutual relationship between economic and environment for better natural resource management. The valuation is also able to describe advantages as well as disadvantages related to policy and managerial options for natural resources and eventually can be expected to achieve fairness in the distribution of benefits derived from natural resource management.

One of the intangible benefits that can be derived from forests is hydrological benefit. There are several previous studies that have calculated economic value of the hydrological benefit from forests. Darusman (1993) has calculated the economic value of hydrological benefit from Gunung Gede Pangrango National Park for household usage that was Rp. 4,341 billion/year or Rp. 280 million/ hectare. Whereas Ramdan et al. (2003) calculated the average economic value

1 Socio Economic and Policy Research Center, Jl. Gunung Batu No. 5 Bogor 16610, Indonesia

2 Corresponding author. E-mail: nurfatriani@yahoo.com 
of hydrological benefit from Gunung Ciremai National Park in West Java for household usage. The average economic value was Rp. 141,575,736.80/person/ year, in total it reached Rp. $3.35 \times 10^{13} /$ year. Table 1 describes completely several studies related to the economic value of hydrological benefit from forests.

Table 1. Forest hydrology value from several studies

\begin{tabular}{|c|c|c|c|c|}
\hline No & Sites & $\begin{array}{l}\text { The Average } \\
\text { economic value } \\
\text { of hydrological } \\
\text { benefit from } \\
\text { forest (Rp/ } \\
\text { person/ year) }\end{array}$ & $\begin{array}{l}\text { Total value } \\
\text { (Rp/year) }\end{array}$ & $\begin{array}{l}\text { Consumer } \\
\text { surplus }(\mathrm{Rp} / \\
\text { year) }\end{array}$ \\
\hline 1 & $\begin{array}{l}\text { Gunung Ciremai National Park } \\
\text { (Ramdan et al., 2003) }\end{array}$ & $141,575,736.80$ & $3.35 \times 10^{13}$ & $3.34 \times 10^{13}$ \\
\hline 2 & $\begin{array}{l}\text { Gunung Halimun National Park } \\
\text { (Widada, 2004) }\end{array}$ & $23,774.80$ & $5,223,870,380$ & $4,060,503,012$ \\
\hline 3 & $\begin{array}{l}\text { Educational forest of Gunung } \\
\text { Walat (Roslinda, 2000) }\end{array}$ & $295,679.25$ & $2,099,618,354$ & $2,084,018,810$ \\
\hline 4 & $\begin{array}{l}\text { Community Forest at Nglipar } \\
\text { Subdistrict, Gunung Kidul } \\
\text { District (Nurfatriani, 2005) }\end{array}$ & $28,745.82$ & $1,007,483,598$ & $702,188,076$ \\
\hline 5 & $\begin{array}{l}\text { Brantas Watershed, East Java } \\
\text { (Ginoga et al., 2005) }\end{array}$ & $179,041.73$ & $76,769,512,989$ & $55,417,898,353$ \\
\hline 6 & $\begin{array}{l}\text { Cirasea Watershed, West Java } \\
\text { (Ginoga et al., 2005) }\end{array}$ & $332,660.59$ & $37,873,740,832$ & $31,474,568,908$ \\
\hline
\end{tabular}

Assessing economic value of the hydrological benefit from forests is useful for the development of management plan, allowing the integration of all marketable and non-marketable values derived from more scarce forest resources. This study is important as an element for policy recommendation for land use allocation especially in comparing between conservation, rehabilitation or exploitation objectives. The economic value of hydrological benefit from forests can reflects how importance forest resource is, not only from marketable commodity but also from environmental services provided by forests.

This paper reports the economic value of hydrological benefit from protecting forests, using Upper Brantas Sub-watershed as a case. Brantas Subwatershed was choosen as the research site according to watershed degradation that occurred at Brantas Sub-watershed currently. Meanwhile, it supports the life system for communities living surround Brantas Sub-watershed since it became the huge watershed in East Java. Hence, the information of the economic value of hydrological benefit from protecting forests in Brantas 
Sub-watershed will be crucial to determine the direction of policy taken for improving the performance of Brantas Sub-watershed.

The scope of this study was limited to the calculation of hydrological benefit from commercial uses of water from the forest, which included: tap/ drinking water, hydro power generation, and industrial uses.

\section{MATERIALS AND METHODS}

This research combined the utilisation and full cost methods. In this study, water was assumed to be a product of protecting forests. The first step was to identify various uses of water resources followed by assessing forest resources including biophysical and socio-economic resources by quantifying any aspect indicating hydrological service provided by the forests. This will produce an estimation of the economic value of water for any usage based on market values.

The full cost of water provision was calculated by internalising environmental costs to be proportionally distributed to the user (beneficiary pay principle). Different cost that has to be paid by different user was used as the basis to calculate a normal tariff for the water usages, one that ensures sustainability. Figure 1 shows analytical framework used in this research. 


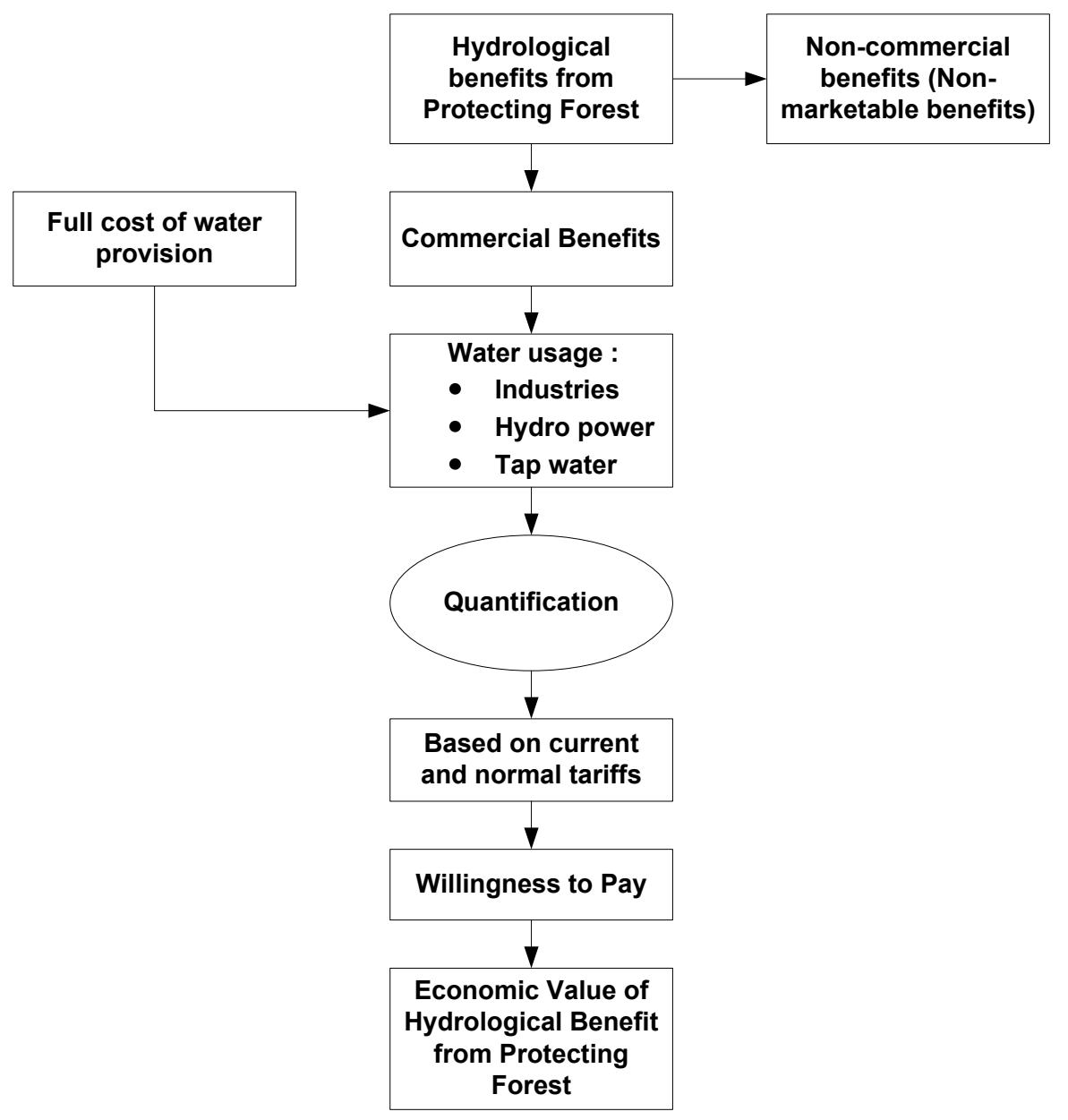

Figure 1. Analytical framework for economic valuation of water for commercial use in the upper Brantas Sub-watershed

\section{A. Research Sites}

This research was conducted in Upper Brantas Sub-watershed, East Java from March to December 2006. Data for calculating the economic value of water for commercial uses was obtained from Jasa Tirta I State Enterprise (PJT I) in Malang, East Java. Brantas Sub-watershed is under the authority of PJT I, which is assigned by the Government to provide water for producing hydro power, irrigation, tap water, and industrial purposes, as well as to mitigate 
flood and maintain water quality. Jasa Tirta I State Enterprise was established through Government Regulation (PP) No. 5/1990 which was renewed by PP No. 93/1990.

Forest management in upper Brantas Sub-watershed varied according to the forest function in each Sub-watershed. There are conservation and protection forests which are managed by Forest Service Office in East Java (R. Soerjo Forest Park), Forest State Enterprise in Malang Region, and Bromo Tengger Semeru National Park office. Those forests have a significant role as a life support system for livelihood in Brantas sub-watershed. The important role of the forest is as a catchment area that benefit community who live surround the forest. There are several springs surrounding the forest which flow the water for household and agricultural usage. Table 2 describes the type and function of the forest, and forest manager institutions.

Table 2. Forests area in upper Brantas sub-watershed

\begin{tabular}{cllc}
\hline No & \multicolumn{1}{c}{ Forest Functions } & \multicolumn{1}{c}{ Management } & Area (Ha) \\
\hline 1 & $\begin{array}{l}\text { Conservation: R. Soerjo } \\
\text { Forest Park }\end{array}$ & $\begin{array}{l}\text { East Java Forest Service } \\
\text { Office }\end{array}$ & $27,868.30$ \\
2 & Protection & $\begin{array}{l}\text { Forest State Enterprise } \\
\text { (Perhutani) in Malang } \\
\text { Region }\end{array}$ & $69,372.00$ \\
3 & $\begin{array}{l}\text { Conservation: Bromo } \\
\text { Tengger Semeru National } \\
\text { Park }\end{array}$ & $\begin{array}{l}\text { Bromo Tengger Semeru } \\
\text { National Park Office }\end{array}$ & $50,276.20$ \\
\hline
\end{tabular}




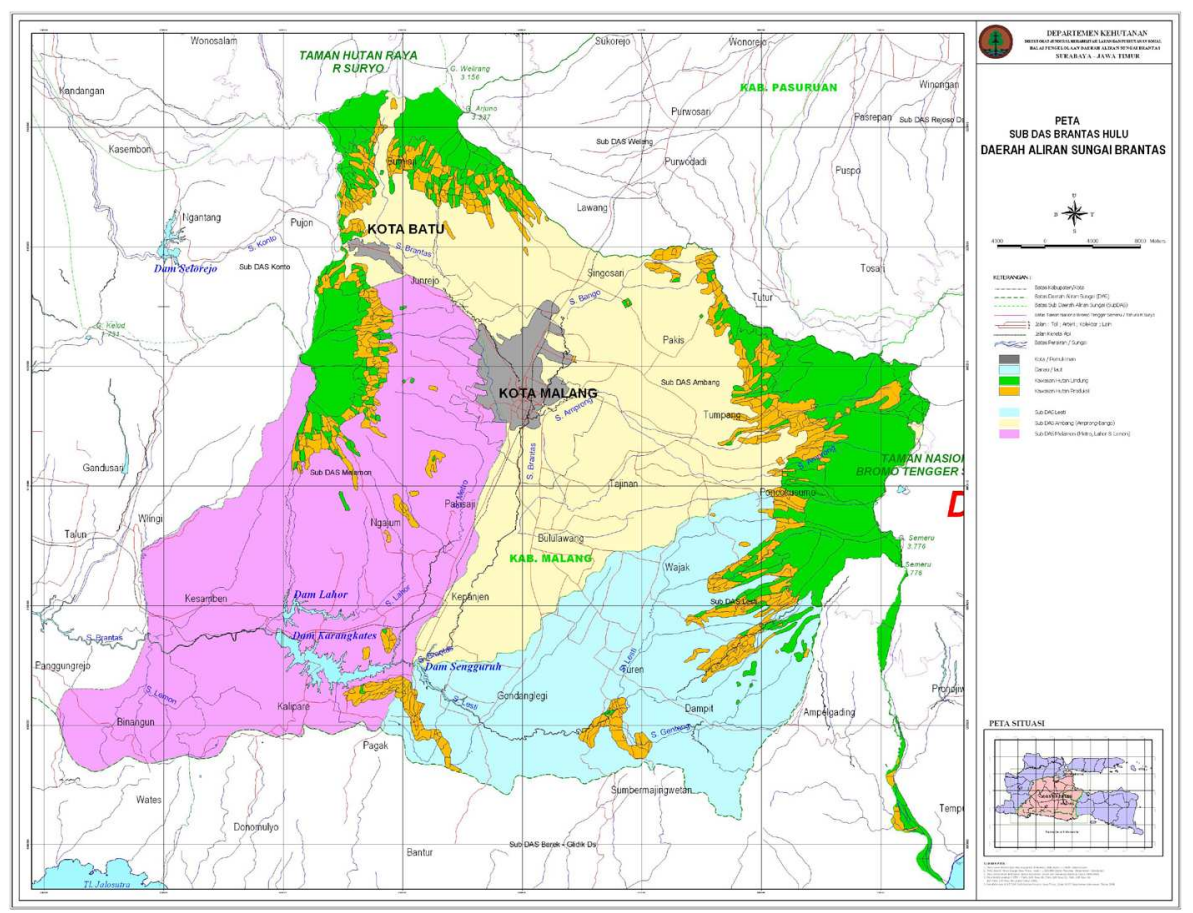

Figure 2. Map of upper Brantas sub-watershed (source: BP DAS Brantas, 2006)

\section{B. Data Collection}

The primary data were obtained through semi-structured interviews of respondents and by observations, while the secondary data were gathered from literature reviews and references provided by related institutions (Jasa Tirta State Enterpise (PJT I), State Electricity Enterprise (PLN), Local Government Owned Water Enterprise (PDAM), Catchment Area Management Authority (BP DAS), Water Management Authority (Dinas Pengairan), State Works (Dinas Pekerjaan Umum), Local Authority for Environmental Impact Management (BAPPEDALDA).

\section{Data Analysis}

The economic valuation of hydrological benefits from protecting forest for several commercial uses was conducted using the market value method (Bishop, 1999). This method required the market value of water and normal tariff of water to be multiplied by volume used. The normal tariff of water was estimated using the full cost method as described in Figure 2. 


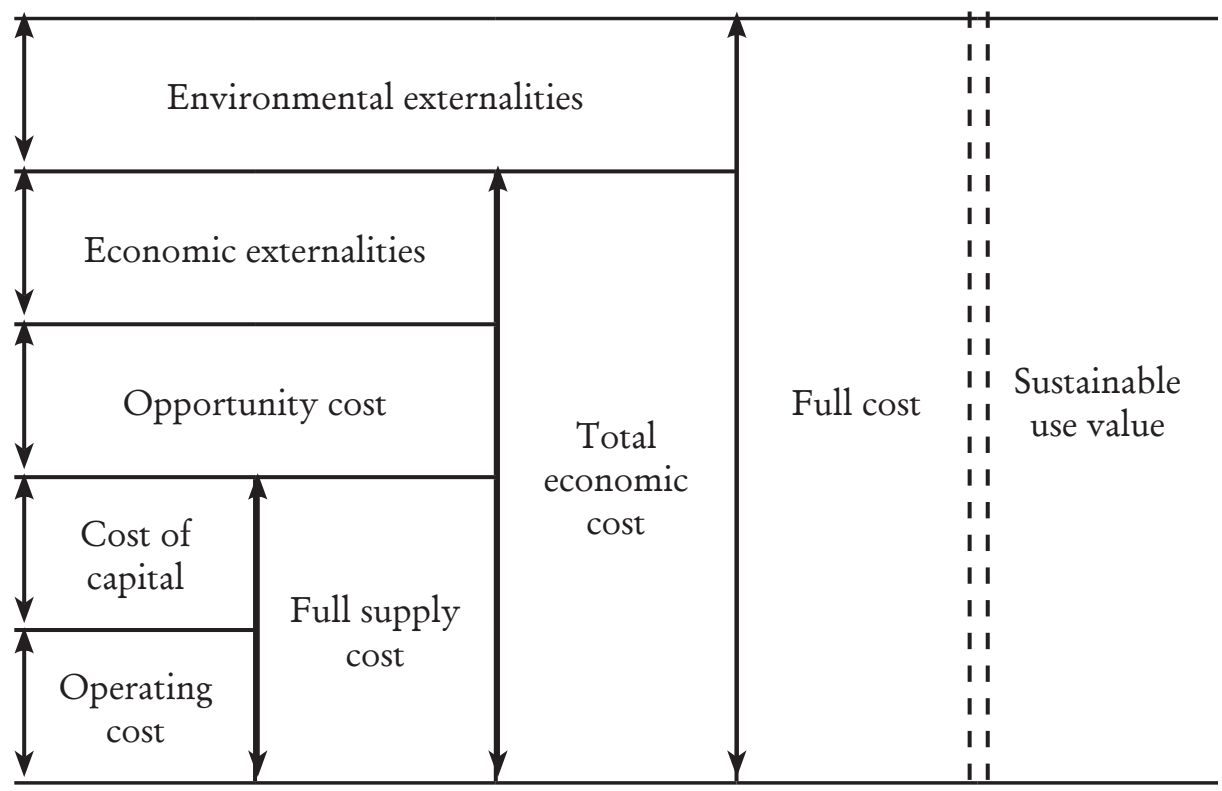

Figure 3. Calculation of the water provision full cost (Rogers et al., 1996)

1. Calculation of costs paid by users

The cost that should be paid by every user was calculated through multiplication of the benefit proportion produced by user with the full cost of water provision as expressed in the following formula:

$U C_{i}=a \% \times F C$

where:

$\mathrm{UC}_{\mathrm{i}}=$ Cost paid by user $\mathrm{i}$

$\mathrm{a} \%=$ Benefit proportion produced by user

$\mathrm{BP}=$ Full cost of water provision

2. Calculation of the normal tariff

The normal tariff for every usage of water was derived from cost paid by each user divided by production volume produced by the user. The formula is as follows: 


$$
N T=\frac{U C_{i}}{Q_{i}}
$$

where,

$\mathrm{NT}=$ Normal tariff

$\mathrm{Q}_{\mathrm{i}}=$ Water volume/wattage of electricity

3. Environmental value

The difference between the current tariff and the normal tariff was considered as an environmental value, which was obtained using the following formula:

$E V=(N T-C T) \times Q_{i}$

where,

$\mathrm{EV}=$ Environmental value

$\mathrm{CT}=$ Current tariff

4. Values of water for industries, hydro power and tap water

The value of water for industries is defined as the value of water usage for industrial purposes, under an assumption that the water is sourced from a dam collecting water produced by forests in the Upper Brantas Sub-watershed. Likewise with the values of water for hydro power generation and tap water. Those values were calculated using Formula 4, 5 and 6, respectively.

$V_{W I}=Q_{W I} \times P_{W I}$

where,

$\mathrm{V}_{\mathrm{WI}}=$ Value of water for industries (Rp./year)

$\mathrm{Q}_{\mathrm{WI}}=$ Volume of water demanded by industries $\left(\mathrm{m}^{3}\right)$

$\mathrm{P}_{\mathrm{WI}}=$ Normal tariff of water for industries - current tariff of water for industries $\left(\mathrm{Rp} . / \mathrm{m}^{3}\right)$

$V_{W H}=Q_{E} x P_{W H}$

where,

$\mathrm{V}_{\mathrm{WH}}=$ Value of water for hydro power (Rp./year)

$\mathrm{Q}_{\mathrm{E}}=$ Electricity output $(\mathrm{kWh})$

$\mathrm{P}_{\mathrm{WH}}=$ Normal tariff of water for hydro power - current tariff of water for hydro power $\left(\mathrm{Rp} . / \mathrm{m}^{3}\right)$ 
$V_{W T}=Q_{W T} \times P_{W T}$

where,

$\mathrm{V}_{\mathrm{WT}}=$ Value of water for tap water (Rp./year)

$\mathrm{Q}_{\mathbb{W T}}=$ Volume of tap water produced $\left(\mathrm{m}^{3}\right)$

$\mathrm{P}_{\mathrm{WT}}=$ Normal tariff of water for tap water - current tariff of water for tap water $\left(\mathrm{Rp} . / \mathrm{m}^{3}\right)$

\section{RESULTS AND DISCUSSION}

The utilisation of water for commercial purposes in Indonesia can be valued on the basis of market price, in the form of a tariff. In the case of Brantas Subwatershed, the tariff was determined by the government. However, in practice, the benefit derived from the tariff determination could not meet the operating cost (Idrus, 2003).

\section{A. Economic Value of Hydrological Benefit from Protecting Forest in Sub Brantas Sub-watershed using the Full Cost Method}

Rogers et al. (1996) proposed a method to calculate the real value of water, i.e. sustainable use value. The method calculated all costs for producing and distributing the water to different types of consumers. The costs included operational and maintenance cost, capital cost, opportuniy cost, and costs expended for environmental rehabilitation as the production process may result in environmental degradation. Hence the value of water has internalised externalities. The following sections discuss how each type of cost was calculated in order to have the total value of water.

1. Operating and maintenance costs of Jasa Tirta I State Enterprise

Operational activities conducted by PJT I included: (1) water allocation; (2) irrigation audit; (3) river audit; (4) flood control; (5) water quality audit; (6) observation of hydrometeorology; and (7) data report and evaluation. Meanwhile maintenance activities in PJT I include: (1) erosion and sedimentation control; (2) river banks maintenance; and (3) main infrastructure maintenance including dam, tunnel and check dams. The operational and maintenance costs in 2001 reached Rp. 95.13 billions and Rp. 106.68 billions in 2005.

To obtain values in 2006, the costs were inflated using wholesale price indices which was turned into an average operating and maintenance cost of Rp. 142.8 billion. The largest proportion of operating and maintenance cost was the cost for maintaining irrigation facilities, counting $59.3 \%$ of the total cost. This cost was a normal cost required by PJT I to operate and was 
influenced by several factors, such as inflation, minimum wages, and buildings. The normal cost also tends to increase as the quality of water decreased and conservation activities increased. According to PJT I document, the operating and maintenance cost was predicted to increase 1-2\% annually from investment cost. Unfortunately, due to limited budget, PJT I could not implement all activies required to maintain their facilities.

\section{Cost of capital}

The cost of capital is defined as the cost for building irrigation facilities which are considered as the asset of PJT I. The facilities include dams, tunnels, channels and pump stations. The value of the capital is the value when the facilities were built. As the facilities were built partly using foreign currency (US\$ and $¥$ ), the value is converted to Indonesian Rupiah (Rp.) using the current rate. Any cost paid in Rupiah is then inflated using price indices. The value of capital owned by PJT I in 2005 was Rp. 8.6 trillion, or reaching Rp. 154 billion per annum.

\section{Opportunity cost}

The opportunity cost of producing water for several purposes is considered zero (0), since there is no better option to the current alternative. The current alternative which is included hydropower, tap water, industry, irrigation, flood management, water quality and management is better than other alternatives such as tourism and aquaculture.

\section{Economic externalities}

Costs or benefits caused by forest degradation or improvement in the upstream will be paid or received by people in the downstream. This is considered as economic externalities. Hence, economic externalities may have positive or negative impacts.

In this research, the economic externalities are approached through sedimentation of dam caused by erosion due to forest degradation. The value is obtained from the change in the cost paid by tap water provider per cubic meter multiplied by the volume produced by the provider (Suparmoko, 2002).

The increase in production cost of water is mainly due to the increase in the amount of chemical addition needed as the quality of water is becoming lower. In particular, the water contains high level of ferrum $(\mathrm{Fe})$; therefore larger chemicals are needed to neutralise it. It is calculated that the economic externality is Rp. 1.67 billion per annum. The value is obtained from averaging economic externalities paid by water companies in Surabaya and Malang 
reflected by their increase in production cost. Table 3 shows how the calculation is conducted.

Table 3. Economic externalities due to forest degradation

\begin{tabular}{|c|c|c|c|c|c|c|}
\hline & Year & $\begin{array}{l}\text { Cost of water } \\
\text { production }\end{array}$ & $\begin{array}{l}\text { Volume of } \\
\text { water (million } \\
\text { m3) }\end{array}$ & $\begin{array}{c}\text { Cost of } \\
\text { production/ } \\
\text { m3 (Rp./m3) }\end{array}$ & $\begin{array}{l}\text { Difference of } \\
\text { production } \\
\text { cost (Rp./ } \\
\text { m3) }\end{array}$ & $\begin{array}{l}\text { Economic } \\
\text { externalities } \\
\text { (Rp./year) }\end{array}$ \\
\hline $\begin{array}{l}\text { State water } \\
\text { company } \\
\text { at Surabaya }\end{array}$ & 2004 & $77,731,913,877$ & $234,211,213$ & 277 & \multirow[t]{2}{*}{14} & \\
\hline City & 2005 & $81,766,917,250$ & $236,513,683$ & 291 & & $3,270,840,985$ \\
\hline $\begin{array}{l}\text { State water } \\
\text { company } \\
\text { at Malang }\end{array}$ & 2004 & $114,218,408$ & $29,910,000$ & 3.82 & \multirow[t]{2}{*}{4.96} & \\
\hline Regency & 2005 & $118,468,415$ & $13,490,000$ & 8.78 & & $66,953,660$ \\
\hline \multicolumn{6}{|c|}{ Average } & $1,668,897,323$ \\
\hline
\end{tabular}

Source: PDAM Kota Surabaya and PDAM Kab. Malang (2006)

5. Environmental externalities

The cost of environmental externalities is approached using environmental rehabilitation activities as a minimum prediction for environmental degradation (Rogers et al., 1996). The degradation of Upper Brantas Sub-watershed was identified from the area of poor lands in R. Soerjo Forest Park, Bromo Tengger Semeru National Park (TNBTS) and protected areas within production forests managed by State Forestry Enterprise. Table 4 shows the calculation of environmental externalities.

Table 4. Environmnetal externalities due to forest degradation

\begin{tabular}{|c|c|c|c|}
\hline Forest Area & $\begin{array}{c}\text { Average } \\
\text { cost of } \\
\text { rehabilitation } \\
\text { (Rp./ha) }\end{array}$ & Poor area (ha) & $\begin{array}{c}\text { Environmental } \\
\text { externalities (Rp./ } \\
\text { year) }\end{array}$ \\
\hline R. Soerjo Forest Park & $1,600,000$ & 4,000 & $6,400,000,000$ \\
\hline State Forestry Enterprise & $1,000,000$ & 9,280 & $9,279,900,000$ \\
\hline $\begin{array}{l}\text { Bromo Tengger Semeru } \\
\text { National Park }\end{array}$ & $2,000,000$ & 1,037 & $2,074,000,000$ \\
\hline \multicolumn{3}{|c|}{ Average } & $17,753,900,000$ \\
\hline
\end{tabular}


The average cost of rehabilitation is calculated from several activities including planting wages, supplies, transport and seedlings. The value of environmental externalities reflects economic value of environmental degradation that has to be returned to the upstream to revive the functions of the forest.

\section{B. Full Cost}

From the previous calculations through several approaches, the value of water based on the full cost method is represented in Figure 3.

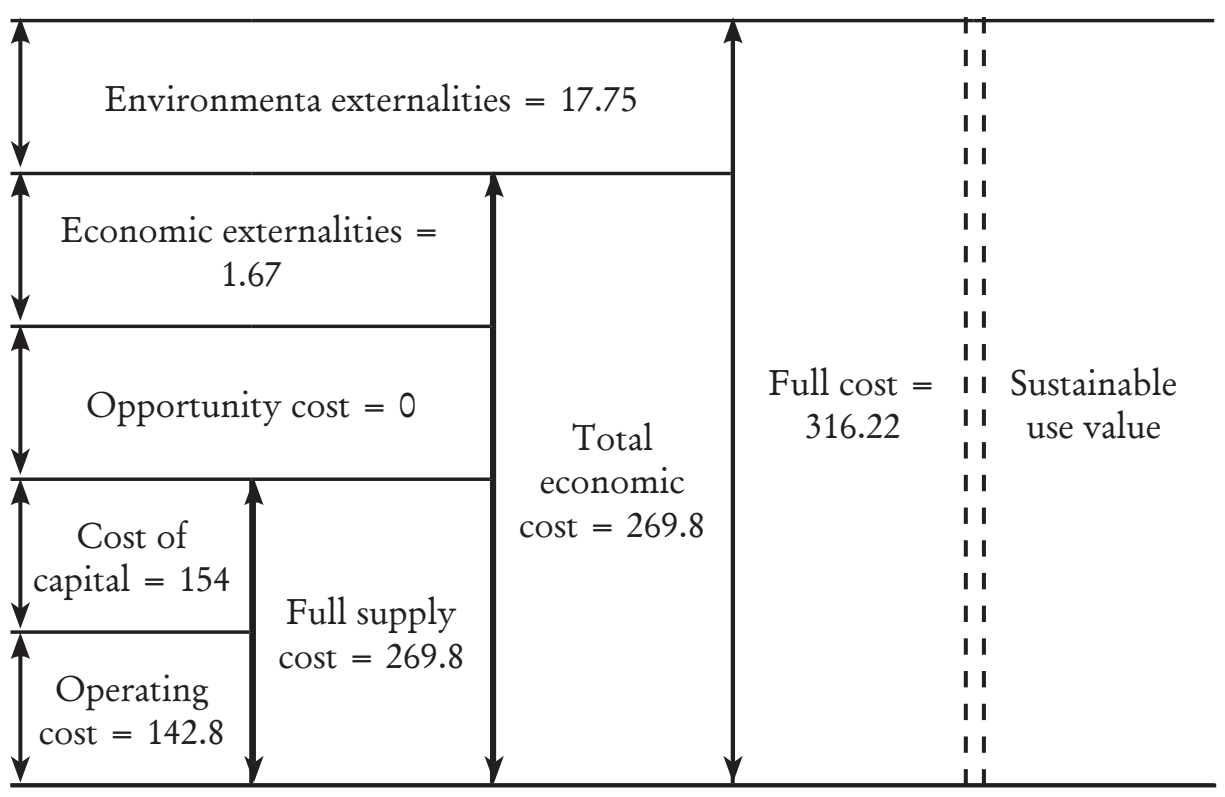

Source: Adapted from Rogers et al. (1996)

Figure 4. Full cost of water supply at Brantas Hulu - billion Rp. per annum

The full cost for providing water, Rp. 316.22 billion per annum, can be used as a basis for determining water tariff as the cost has covered the value of water utilisations along the stream. The tariff is calculated by allocating the full cost proportionally to the users using simplified benefit based method with cost centre approach. Table 5 shows the allocation of cost for different users. 
Table 5. Proportion of benefit and cost that has to be paid by user

\begin{tabular}{lcc}
\hline \multicolumn{1}{c}{ Use } & Percentage of benefit (\%) & $\begin{array}{c}\text { Allocated cost } \\
\text { (Rp. billion/year) }\end{array}$ \\
\hline a. Electricity & 36.20 & 114.47 \\
b. Tap water & 18.17 & 57.46 \\
c. Industries & 24.70 & 78.11 \\
$\quad$ Sub total & 79.07 & 250.04 \\
d. Irrigation & 18.27 & 57.77 \\
e. Flood control & 0.83 & 2.62 \\
f. Water quality & 1.83 & 5.79 \\
$\quad$ Sub total & 20.93 & 66.19 \\
$\quad$ Total & 100.00 & 316.22 \\
\hline
\end{tabular}

Source: PJT I (2006), Recalculated

Irrigation, flood control and water quality audit are activities assigned by the government to PJT I as public services. The benefit value of irrigation is obtained from the revenue resulting from agricultural land using the irrigation water. The value of flood control is obtained from the reduction of lost due to flooding prevention. The water quality is valued from water used for reducing erosion and sedimentation.

By averaging production volumes for each usage, a normal tariff is then obtained. The tariff is calculated by dividing the cost with by the volume. Table 6 shows the normal tariffs for each usage.

Table 6. Production and normal tariff for several purposes

\begin{tabular}{llll}
\hline \multicolumn{2}{c}{ Production per Annum } & \multicolumn{2}{c}{ Normal Tariff } \\
\hline a. Electricity (billion $\mathrm{kWh}$ ) & 0.98 & a. Electricity (billion $\mathrm{kWh}$ ) & 116.70 \\
b. Tap water (billion $\mathrm{m}^{3}$ ) & 0.26 & b. Tap water $\left(\right.$ billion $\mathrm{m}^{3}$ ) & 217.79 \\
c. Industries (billion $\mathrm{m}^{3}$ ) & 0.13 & c. Industries (billion $\mathrm{m}^{3}$ ) & 607.34 \\
\hline
\end{tabular}

The normal tariffs are ideal tariffs to cover the total production cost including externalities. The normal tariffs are higher than the current tariffs; 
therefore the difference between the two types of tariff is considered as the environmental value that should be returned to the upstream.

\section{CONCLUSIONS AND RECOMMENDATIONS}

The value of hydrological benefits from protecting forest can be assessed using a combination of the full cost method and the multiple uses method. The research reveals that the value of benefit is higher than current users paid for, reflected by the higher nominal value of the normal tariffs as compared to that of current tariffs. This leads to a policy implication that the government may increase the tarrifs for water supplied by PJT I, which in turn will enable an increase in the budget for environmental conservation and rehabilitation.

Yet, it is realised that the policy is difficult to implement as the national economy is not adequately condusive. However, gradual internalisation of the externalities will also help the natural resources to provide benefit sustainably and eventually contribute to the economic development.

\section{REFERENCES}

Bishop JT. 1999. Valuing forests: A review of methods and applications in developing countries. International Institute for Environment and Development. London.

Darusman, D. 1993. Nilai ekonomi air untuk pertanian dan rumah tangga: studi kasus di sekitar Taman Nasional Gunung Gede Pangrango. Makalah pada Simposium Nasional Permasalahan Air di Indonesia di Institut Teknologi Bandung.

Idrus, H. 2005. Kajian pemberlakuan tarif dalam bidang usaha di Perum Jasa Tirta II. Perusahaan Umum Jasa Tirta II.

Ginoga K, F. Nurfatriani, Y. C. Wulan, D. Djunaedi, M. Lugina, and C. B. Darmi. 2005. Kajian nilai ekonomi manfaat hidrologis hutan lindung. Laporan Hasil Penelitian. Puslit Sosial Ekonomi dan Kebijakan Kehutanan. Bogor.

Nurfatriani, F. 2005. Nilai ekonomi kawasan yang direhabilitasi (Hutan dan Lahan) Studi Kasus Proyek RHL Kecamatan Nglipar Kabupaten Gunung Kidul, Di Yogyakarta. Karya Siswa Program Master. IPB.

Perum Jasa Tirta I. 2005a. Usulan penyesuaian tarif biaya jasa pengelolaan sumber daya air (d/h Iuran pembiayaan O\&P prasarana pengairan) di wilayah kerja Perum Jasa Tirta I Tahun 2005 untuk PDAM dan Industri. Perum Jasa Tirta I. Tidak Diterbitkan. 
Perum Jasa Tirta I. 2005b. Usulan penyesuaian tarif biaya jasa pengelolaan sumber daya air di wilayah Sungai Kali Brantas tahun 2006 untuk pembangkitan listrik. Perum Jasa Tirta I. Tidak Diterbitkan.

Perum Jasa Tirta I. 2005c. Kewajiban pelayanan umum (KPU) atau public service obligation (PSO) dalam pengelolaan sumber daya air di wilayah kerja Perum Jasa Tirta I Tahun 2005. Perum Jasa Tirta I. Tidak Diterbitkan.

Perum Jasa Tirta I. 2005d. Pedoman operasi dan pemeliharaan di DAS kali Brantas. Perum Jasa Tirta I. Tidak Diterbitkan.

Ramdan, H., Yusran dan D. Darusman. 2003. Pengelolaan Sumberdaya Alam dan Otonomi Daerah: Perspektif Kebijakan dan Valuasi Ekonomi. Alqaprint, Jatinangor, Sumedang.

Rogers P, R. Bhatia dan A. Huber 1996. Water as a sosial and economic good: How to put the principle into practice. Global Water PartnershipTechnical Advisory Committee. Unpublished.

Roslinda E. 2002. Nilai ekonomi hutan pendidikan Gunung Walat dan kontribusinya terhadap masyarakat sekitar [tesis]. Bogor: Institut Pertanian Bogor, Program Studi Ilmu Pengetahuan Kehutanan.

Suparmoko. 2002. Buku Pedoman Penilaian Ekonomi: Sumberdaya Alam dan Lingkungan (Konsep dan Metode Penghitungan). BPFE. Yogyakarta. 
